\title{
気泡核生成を組み込んだ微細射出発泡 成形シミュレーション技術の開発
}

Chia-Hsiang Hsu ${ }^{* 1} \cdot$ Yuan-Jung Chang*1 後 藤 昌 人*2 田 中 久 博*2 秋 元 英 郎*3

\section{1.はじめに}

プラスチックの成形加工に扔いて，シミュレーションの 重要性は高まる一方である. 射出成形のシミュレーション は完全三次元流動解析が可能になってから急速にその解析 精度が高まってきた，精度が高まると，市場からの新たな 要求も生まれるため, 改良改善が続けられている. 射出発 泡成形のシミュレーションに対する市場からの要求は古く から存在していたが, 後述するように計算要素として考慮 すべき要因が非常に多岐に渡るため, 満足できるシミュ レーションができていなかった.

一方で, 自動車部品の軽量化や電気電子機器の寸法精度 向上等のニーズに合わせて, 超臨界流体を発泡剂に用いる 微細射出発泡成形の応用範囲が急速に拡大してきた。 その

Development of CAE for Physical Foaming Incorporating Cell Nucleation

*1 Chia-Hsiang Hsu/Yuan-Jung Chang

Tai Yuen Hi-Tech Industrial Park, 8 F-2, No.32, Taiyuan St. Chupei City, Hsinchu County 302, Taiwan mail@moldex3d.com

*2 Goto, Masato/Tanaka, Hisahiro 株セイロジャパン MoldexSC 春日部市谷原 3-1-8（テ344-0065） m-goto@saeilo.co.jp

*3 Akimoto, Hideo 秋元技術士事務所 千葉市美浜区中瀬 1-3 幕張テクノガーデン CB 棟 $3 \mathrm{~F} \mathrm{MBP}$ (宁 261-0023) 2019.8. 1 受理

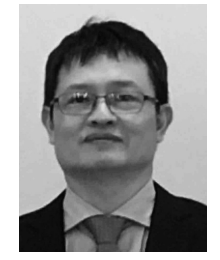

*1 Chia-Hsiang Hsu

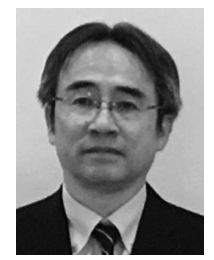

*2 Tanaka, Hisahiro

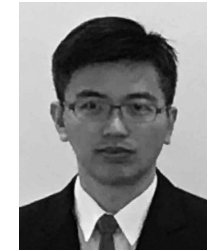

*1 Yuan-Jung Chang

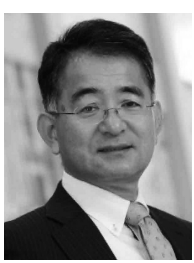

*3 Akimoto, Hideo

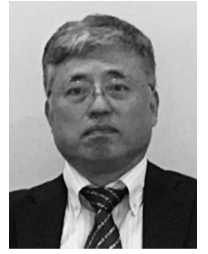

*2 Goto, Masato
ような市場環境を背景に，設計開発段階において実用性の ある微細射出発泡成形シミュレーション技術を求める声が 強まってきた.

我々はそのような市場の要求に応えるべく, 京都大学の 基礎研究の成果である気泡核生成の実験式を組み込んで, 実用レベルの微細射出発泡成形のシミュレーション技術を 確立することに成功し，市場に提供するに至った．今回そ れが評価されて「青木固」技術賞を受賞することになった ので，本技術について解説する.

\section{2. 微細射出発泡成形とは}

微細射出発泡成形とは超臨界流体を発泡剤として用いた 射出発泡成形であり, マサチューセッツ工科大学 (MIT) で開発された。その代表的な技術はMIT 発のベンチャー 企業である TREXEL Inc. (アメリカマサチューセッッ州) が販売している MuCell ${ }^{\circledR}$ 技術である.

微細発泡成形の開発の発端は, MIT と Eastman Kodak による共同開発であり，プラスチック製品の強度を落とす ことなく，プラスチックの使用量を減らして化石資源の使 用を減らしたいという動機であった。プラスチックの強度 を決定しているのは微小な構造欠陥の存在であり, その構 造欠陥よりも小さな気泡であれば強度を落とさないと考え， ミクロンオーダーの微細な気泡を多数含んだ発泡体の製造 技術の開発を開始し, 超臨界流体を発泡剂として用いる物 理発泡によって微細な気泡を多数発生させる技術にたどり 着いた。 その後，事業を TREXEL 社に移管して実際の射 出成形や押出成形に使える技術に仕上げ，世界中にライセ ンスされた（現在押出発泡に関しては，MuCell Extrusion LLC.によって販売されている).

現実には, 構造欠陥よりも小さい気泡は得られていない が, 軽量化や寸法精度等の利点が多く確認されたことで, 広く活用されている。気泡が小さいことを利用しているの ではなく, 気泡の拡大が流動を支援し, 固化収縮分を気泡 の拡大で補うことが多くの利点を生み出している.

我が国でも早期から微細射出発泡成形技術の実用化検討 が行われた．国内で最初に実用化された製品は，侏多ギ セイコーによるコピー機用製品であり, 反りが小さいこと が認められて採用になった。 


\section{3. 微細射出発泡成形の原理}

微細射出発泡成形の工程は, (1)可塑化された樹脂に発泡 剂である超臨界流体を注入する工程, (2)射出成形機のスク リューによって溶融樹脂と超臨界流体を混合する工程，(3) 射出成形機の背圧（飽和圧力以上）によって発泡剂を完全 溶解して射出を待つ工程, (4)射出されて金型キャビティに 流れ込みながら気泡核を生成する工程, (5)気泡が成長する 工程，(6)金型を樹脂と気泡によって満たして充填を完了さ せる工程, (7)冷却固化させる工程, 8)製品を取出す工程か ら成り立っている。

すなわち，通常の射出成形に比べると超臨界流体を注入 してから完全溶解させるまでの工程と金型キャビティ内で 気泡核が生成する工程, 気泡が成長して, 気泡の成長が停 止（充填完了と樹脂の冷却固化による）する工程が追加さ れる。その分だけ工程が複雑になり，微妙な条件のずれが 成形不良につながりやすく, 難易度が高い成形技術である.

微細な気泡を多数得るための運転上のポイントは, 発泡 剂を大量に溶解させ, 急減圧によって過飽和状態を形成す ることにあり，成形条件によって気泡の状態は大きく影響 される，発生する気泡核が多いほど，1個当たりの気泡は 小さくなる.

また，通常の射出成形の常識にとらわれていると，正し い製品設計，金型設計や成形条件の設定ができないことが 多い，例えば，ゲートは板厚が薄い部分に設け，板厚が薄 い方から厚い方に流動させる，流動末端付近にあるリブの 充填が困難な場合はリブ厚みを増すと重量が軽くなる等の 設計ノウハウは直感的には理解しにくい.

\section{4. 微細射出発泡成形シミュレーションの従来技術と 課題}

前述のように，発泡成形は融かして流して固める工程に 加えて, 気泡核の生成・気泡の成長・気泡成長の停止の工 程が同時並行で起こるため非常に複雑である. 従来から微 細射出発泡成形用シミュレーションは存在していたが，そ の解析精度は実用レベルからほど遠いものであった。図 1 のように初期のシミュレーションは, 気泡密度を一定とし て気泡成長のみを解析していた。 その理由は, 気泡核生成 理論が未確立であり，シミュレーションに組み込む理論式 が確立していなかったためである.

実用性・信頼性があるシミュレーション技術の確立のた めには，気泡核生成を組込み，気泡核生成を計算するため のパラメーターの決定技術の確立, 計算結果と実際の成形 の突合せ技術の確立が必要であった。

実際の微細射出発泡成形では気泡核の生成は均一でなく 圧力分布に依存し, 図 2 のように気泡密度により気泡径及 び気泡成長が大きく影響を受ける，すなわち，図 3 のよう に飽和圧力以下の領域で発泡核が発生し成長する．微細射 出発泡成形の解析精度向上には, 気泡核すなわち気泡密度 の高精度な予測が不可欠であった. 我々の課題は, 気泡核 の生成過程を含むシミュレーション技術を開発して, 微細 射出発泡成形のシミュレーションを実用レベルに高めるこ とであった.

既に瀧ら ${ }^{1)}$, 2)により気泡核生成モデルが提案されていた

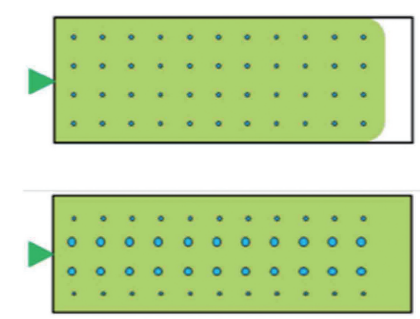

Fig. 1 Conventional CAE

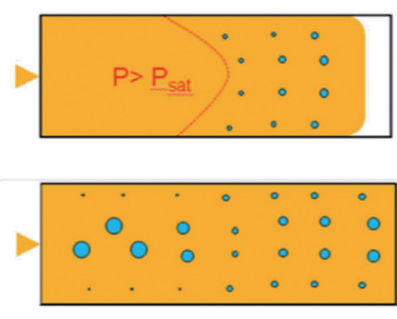

Fig. 2 Actual foaming

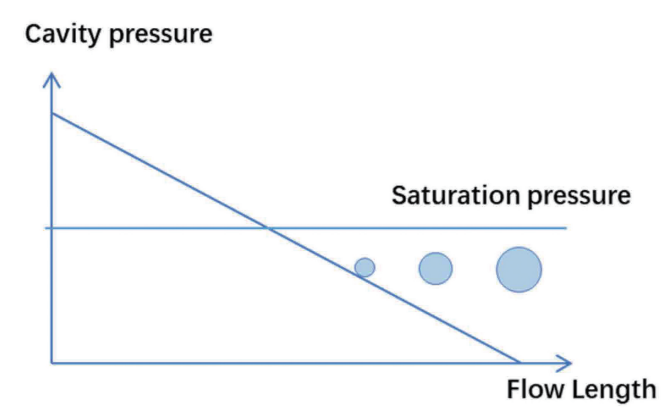

Fig. 3 Shape of faming correlation diagram

が，既存技術では，気泡核生成モデルを用いての CAE 解 析は計算メモリー容量及び解析時間等で実用的でなかった. また, 複合材等は可視化測定不可能で気泡核生成パラメー ター值を特定する技術が確立されていなかった.

\section{5 . 課題解決のアプローチ}

\section{1 計算における課題}

前述の技術的課題を解決するために，下記のアプローチ を実施した。(1)気泡核生成式の組込み，(2)均質化手法によ る計算負荷低減, (3)微細メッシュ, (4)表面層における BLM メッシュの採用，(5)低せん断領域の粘度式理論の構築， (6) リバースエンジニアリング手法による発泡パラメーターの 算出技術構築である. 以下それぞれのアプローチについて 説明する.

\section{2 気泡核生成式の組込み}

気泡核生成式は下記のバッチ発泡の可視化実験から得ら

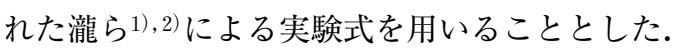

$$
\mathrm{J}(\mathrm{t})=\mathrm{f}_{0}\left(\frac{2 \gamma}{\pi \mathrm{m}}\right)^{\frac{1}{2}} \exp \left(-\frac{16 \pi \gamma^{3} \mathrm{~F}}{3 \mathrm{~K}_{\mathrm{B}} \mathrm{T}\left(\overline{\mathrm{c}}(\mathrm{t}) / \mathrm{K}_{\mathrm{H}}-\mathrm{P}_{\mathrm{c}}(\mathrm{t})\right)^{2}}\right) \mathrm{N}_{\mathrm{A}} \overline{\mathrm{c}}(\mathrm{t})
$$

ここで, $\mathrm{J}(\mathrm{t})$ は核生成速度式, $\mathrm{f}_{0}$ と $\mathrm{F}$ は, 気泡の核生成 率の固定パラメーター, 当たりの質量, $\mathrm{K}_{\mathrm{B}}$ はボルツマン定数, $\mathrm{T}$ は温度, $\overline{\mathrm{c}}(\mathrm{t})$ は 平均濃度, $\mathrm{t}$ は時間, $\mathrm{K}_{\mathrm{H}}$ はヘンリー定数, $\mathrm{P}_{\mathrm{c}}(\mathrm{t})$ は雲囲気 圧力である. 平均ガス濃度は式(2)で表す。

$$
\overline{\mathrm{c}}(\mathrm{t}) \mathrm{V}_{\mathrm{L} 0}=\mathrm{c}_{0} \mathrm{~V}_{\mathrm{L} 0}-\int_{0}^{\mathrm{t}} \frac{4 \pi}{3} \mathrm{R}^{3}\left(\mathrm{t}-\mathrm{t}^{\prime}, \mathrm{t}^{\prime}\right) \frac{\mathrm{P}_{\mathrm{D}}\left(\mathrm{t}-\mathrm{t}^{\prime}, \mathrm{t}\right)}{\mathrm{Rg}_{\mathrm{g}} \mathrm{T}} \mathrm{J}\left(\mathrm{t}^{\prime}\right) \mathrm{V}_{\mathrm{L} 0} \mathrm{dt^{ \prime }}
$$

ここで, $\mathrm{V}_{\mathrm{L} 0}$ は高分子相の体積, $\mathrm{R}\left(\mathrm{t}-\mathrm{t}^{\prime}, \mathrm{t}\right)$ は時刻 $\mathrm{t}^{\prime}$ に生 成した気泡が $\mathrm{t}-\mathrm{t}^{\prime}$ 間成長した半径, $\mathrm{P}_{\mathrm{D}}\left(\mathrm{t}-\mathrm{t}^{\prime}, \mathrm{t}\right)$ は時刻 $\mathrm{t}^{\prime} に$ 生成した気泡が $\mathrm{t}-\mathrm{t}^{\prime}$ 間成長した気泡内圧, $\mathrm{Rg}$ は気体定数 を示す.

気泡径の成長は式(3)で表し，ガス拡散は式(4)で表す. 


$$
\begin{aligned}
& \frac{\mathrm{dR}}{\mathrm{dt}}=\frac{\mathrm{R}}{4 \eta}\left(\mathrm{P}_{\mathrm{D}}-\mathrm{P}_{\mathrm{c}}-\frac{2 \gamma}{\mathrm{R}}\right) \\
& \frac{\partial_{\mathrm{c}}}{\partial_{\mathrm{t}}}=\mathrm{D}\left[\frac{1}{\mathrm{r}^{2}} \frac{\partial}{\partial_{\mathrm{r}}}\left(\mathrm{r}^{2} \frac{\partial \mathrm{c}}{\partial \mathrm{r}}\right)\right]
\end{aligned}
$$

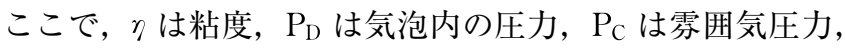
$\mathrm{r}$ は半径, c はガス濃度, D はガス拡散係数を示す.

\section{3 均質化手法による計算負荷低減}

実際は，核生成モデル1),2)では発泡タイミングの違いに より様々なサイズの気泡が混在し, エレメント内には大き さも位置もバラバラな気泡が存在する.ここで, 図 4 のよ うに解析エレメント毎に, 気泡径を平均化し, また気泡位 置も均一分散として扱って計算する。すなわち， 1 個 1 個 の気泡に対して計算するのではなく，気泡群として計算す る. 均質化手法を取り入れて均質化処理での計算を行うこ とでメモリー消費及び計算負荷を大幅に低減した。

\section{4 最適メッシュ（微細メッシュと BLM）}

平均化手法をとることでのデメリットとして解析エレメ ント内での温度分布などの差異が大きいと誤差が大きくな る. 図 5 のように均質化手法での精度を確保するために解 析メッシュセルの微細化が可能な大容量計算能力だけでな く，解析メッシュに BLM（バウンダリー・レイヤ・メッ シュ）を活用して温度が急速に変化する金型境界面付近に プリズムエレメントを多数層（片側 11 層）作成すること で各メッシュセル内での温度のばらつきを抑えて高精度な 解析を可能にした.

また，基礎実験が等温変圧環境でのモデルとなっている がこれを変温変圧環境でも扱えるように改良を加えた。

\section{5 低せん断領域の粘度式}

粘度は発泡に大きく影響するがガラス繊維やセルロース ナノファイバー $(\mathrm{CNF})$ 入りの複合材などでは, 低せん 断領域での流動降伏值が発生する. そこで, 式(5)に示す流 動降伏項付 Cross モデルを適用することによって, 低せん 断域での流動降伏值を表現でき誤差を抑えることができ る3). 図 6 にポリアミド 6 (以下PA 6 (Neat)) とPA 6

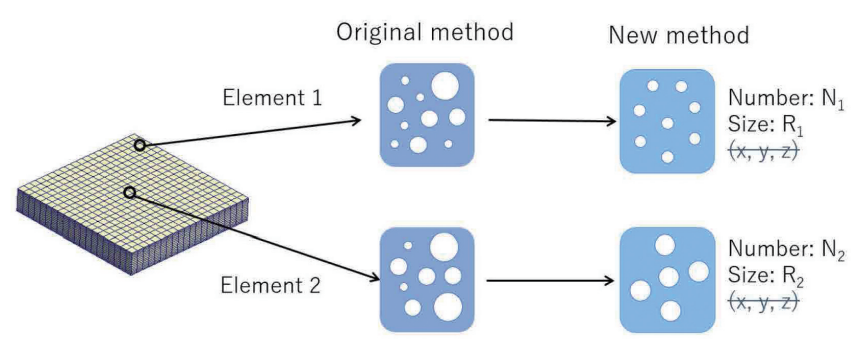

Fig. 4 Homogenization treatment
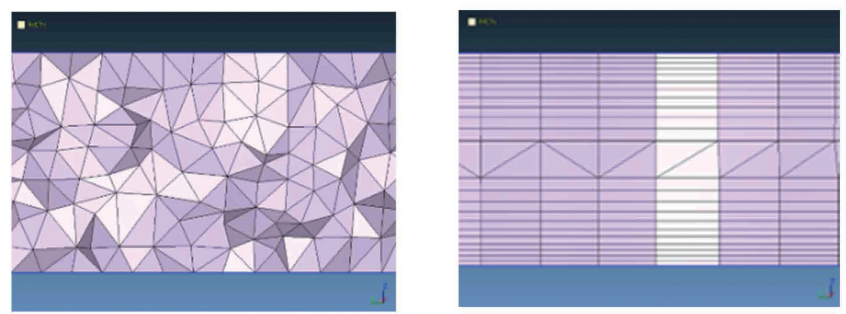

Fig.5 Tetra mesh VS. BLM (boundary layer mesh)

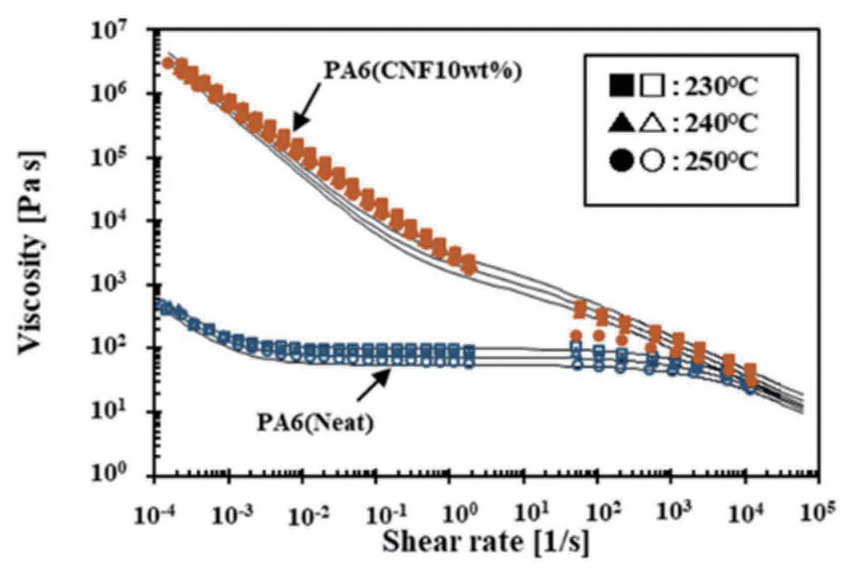

Fig. 6 Viscosity data PA 6 neat and with CNF 10 wt\%

に CNF $10 \mathrm{wt} \%$ 複合させた材料（以下 PA 6 (CNF $10 \mathrm{wt}$ \%)）のせん断粘度曲線を示す. 発泡のステージでの一般 的なせん断速度の $10^{0} \sim 10^{1} 1 / \mathrm{s}$ では, 一桁以上の粘度差が 発生しているのが確認できる.

$$
\eta=\frac{\tau y}{\dot{\gamma}}+\frac{\eta_{0}}{1+\left(\eta_{0} \dot{\gamma} / \tau^{*}\right)^{1-n}}
$$

ここで, $\eta$ は粘度, $\tau_{y}$ は流動降伏值, $\dot{\gamma}$ はせん断速度, $\eta_{0}$ はゼロシェア粘度, $\tau^{*}$ はフィティング係数, $n$ は流れ指 数を示す.

$5.6 \mathrm{X}$ 線 CT 利用したリバースエンジニアリング手 法による発泡パラメーターの算出技術

実際に気泡核生成式をシミュレーションのプログラムに 組み込んでも，使用する材料によって各パラメーターがま ちまちであるという課題があった。 そこで, 実用可能なパ ラメーター決定技術の確立を行った．特に不透明な樹脂及 び繊維入りの樹脂は可視化観察が不可能である。しかし可 視化観察不可能な材料が圧倒的に多く, 不透明材料におけ る各パラメーターの決定技術の確立が解析精度向上に不可 欠であった。

ここで，パラメーター決定の例を示す．CNF が 10\% 添 加されたPA 6 を微細射出発泡成形で製作したダンベル型 試験片（図 7）の中央部の CT 断面画像（図 8）を肉厚方 向に画像処理することで肉厚方向の気泡径と気泡密度分布

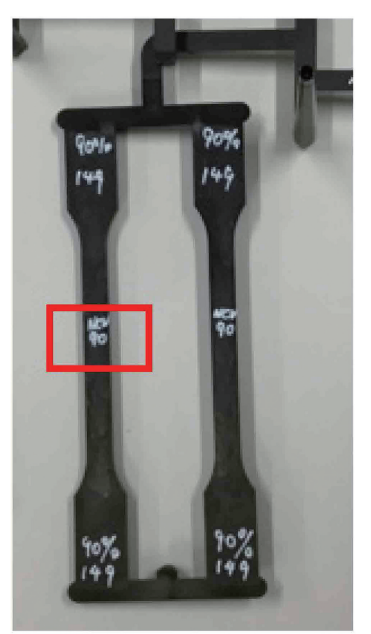

Fig. 7 Dumbbell sample

成形加工 第 31 巻 第 10 号 2019 


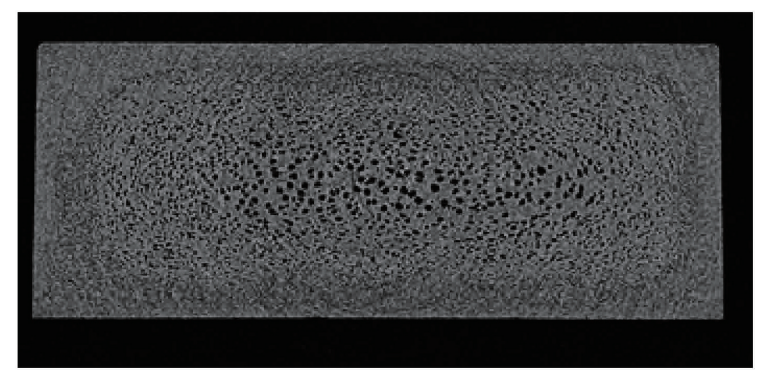

Fig. 8 CT scan data

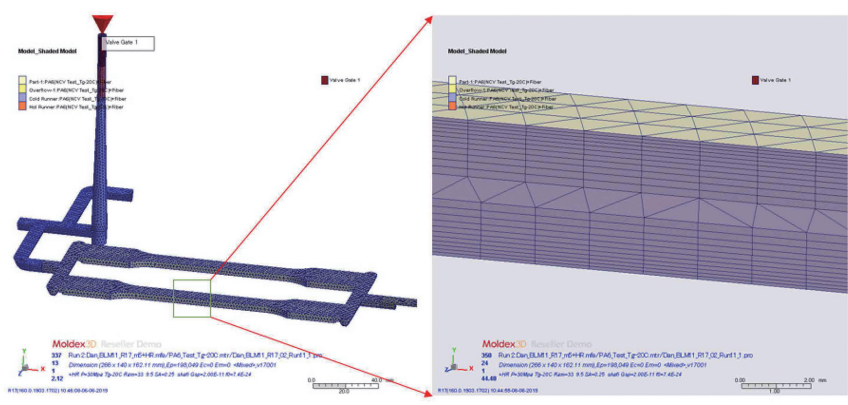

Fig. 9 CAE Model

を求め，これらのデータからリバース技術で核生成率の固 定パラメーター $\mathrm{f}_{0}$ 及び $\mathrm{F}$ を算出する一連の手法を確立 しだ).

\section{6. 算出核生成率パラメーター解析と実測值の比較}

上記技術で算出した気泡径及び気泡密度分布からパラ メーターを算出して解析を行った。解析モデルを図 9 に 示す.

ダンベル型試験片中央部の肉厚に対する平均気泡径及び 気泡密度分布図を最適化無しの CAE 解析值（デフォルト 值のまま計算), 最適化後の解析値, 実測值を図 10 に示す. 実用上でより重要性が高い平均気泡径がよく一致している.

\section{7.おわりに}

不透明な樹脂及び繊維が入った樹脂も含め，微細射出発 泡成形シミュレーションに気泡核生成モデルを効率よく計 算できるよう組込み，メモリー及び計算時間が実用的なシ

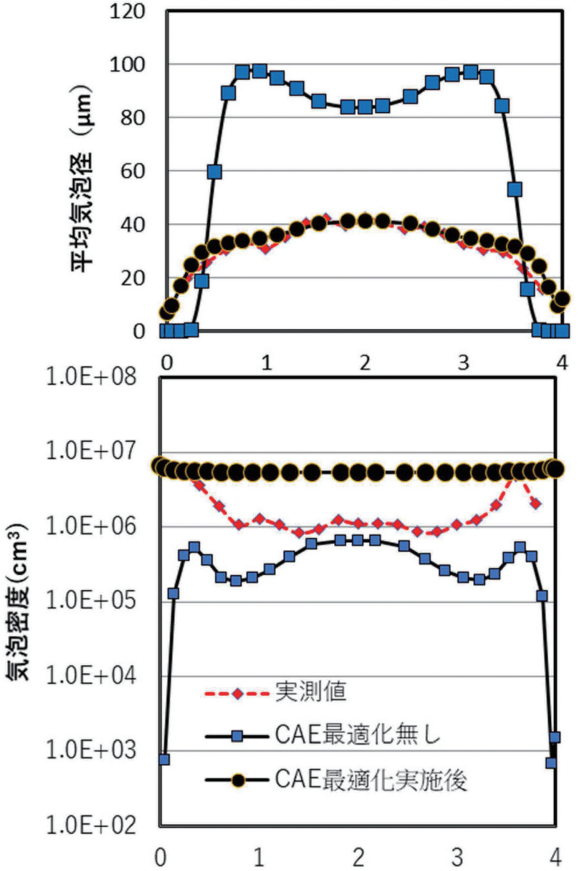

Fig. 10 Cell size and Cell Density vs. Thickness Layer

ステムを開発した．本技術は完全三次元流動解析ソフト $\lceil$ Moldex $3 \mathrm{D} 」$ のオプションとして既に多くの企業や研究 機関に採用されている.

\section{謝辞}

気泡核生成モデルの提供及び助言いただいた京都大学 大嶋正裕教授ならび金沢大学 瀧健太郎准教授に謝辞を申 し上げます。

\section{参 考 文 献}

1) 瀧健太郎，大槻安彦：成形加工，18(3)，205(2006)

2) Taki, K. : Chem. Eng. Sci., 63.3643(2008)

3 ) 中井元徳, 田中久博, 井上尊勝, 新留仁誉, 後藤昌人 : 成形加工'18，301 (2018)

4）杉尾太陽, 後藤昌人, 田中久博, 今嶋晋一, 秋元英郎 : 成形加工'16，13(2016) 